Article

\title{
Microbial Strategies for Cellulase and Xylanase Production through Solid-State Fermentation of Digestate from Biowaste
}

\author{
Laura Mejias ${ }^{1,2}$, Alejandra Cerda ${ }^{1}$, Raquel Barrena ${ }^{1}$, Teresa Gea ${ }^{1, *(1)}$ and Antoni Sánchez ${ }^{1}$ \\ 1 GICOM Research Group, Department of Chemical, Biological and Environmental Engineering, \\ School of Engineering, Edifici Q, Universitat Autònoma de Barcelona, 08193 Bellaterra, Barcelona, Spain; \\ laura.mejias@uab.cat (L.M.); alejandra.cerda@uab.cat (A.C.); raquel.barrena@uab.cat (R.B.); \\ antoni.sanchez@uab.cat (A.S.) \\ 2 Aeris Tecnologías Ambientales S.L., Carrer Santa Rosa, 38, local, 08290 Cerdanyola del Vallès, \\ Barcelona, Spain \\ * Correspondence: teresa.gea@uab.cat; Tel.: +34-935-812694; Fax: +34-935-812013
}

Received: 15 June 2018; Accepted: 7 July 2018; Published: 12 July 2018

\begin{abstract}
Solid-state fermentation (SSF) is a promising technology for producing bioproducts from organic wastes. The objective of this study is to assess the feasibility of using digestate as substrate to produce hydrolytic enzymes, mainly cellulase and xylanase, by exploring three different inoculation strategies: (i) SSF with autochthonous microbiota; (ii) non-sterile SSF inoculated with Trichoderma reesei and (iii) sequential batch operation to select a specialized inoculum, testing two different residence times. Native microbial population did not show a significant cellulase production, suggesting the need for a specialized inoculum. The inoculation of Trichoderma reesei did not improve the enzymatic activity. On the other hand, inconsistent operation was achieved during sequential batch reactor in terms of specific oxygen uptake rate, temperature and enzymatic activity profile. Low cellulase and xylanase activities were attained and the main hypotheses are non-appropriate biomass selection and some degree of hydrolysis by non-targeted proteases produced during fermentation.
\end{abstract}

Keywords: cellulase; digestate; solid-state fermentation; specialized inoculum; xylanase

\section{Introduction}

The EU has, over the years, defined stronger directives to reduce biowaste diversion to landfill (199/31/EC), due to the gaseous emissions generated (up to 3\% of the total GHG emissions) [1]. Anaerobic digestion (AD) is a well-established technology that successfully treats biowaste, stabilizing the organic matter to produce energy, while also generating another product: digestate. The latter is a nutrient-rich material mainly composed of microbial biomass and recalcitrant organic matter, formed from the degradation of readily biodegradable compounds by the AD process. Characteristics of digestate make it an ideal replacement of inorganic fertilizers [2]. However, digestate is not fully stabilized and this necessitates a hygienization and stabilization process (such as composting) of the material, prior to its use as soil amendment [3]. Although digestate from sewage sludge has been widely studied, only a few studies assess the potential uses of digestate from biowaste and its potential effect on soil in agronomic applications [4,5]. In this framework, the DECISIVE project (www.decisive2020.eu) aims at providing a new solution to biowaste management based on decentralized anaerobic digestion and the valorisation of digestate through solid-state fermentation.

Solid-state fermentation (SSF) is described as the biotransformation that takes place in a solid matrix in the absence or near absence of free water [6]. SSF has received extra attention over the last few years as researchers explored the production of added-value compounds such as enzymes, antibiotics, 
bioactive compounds, biological control molecules, etc., by using biomass or by-products from other processes $[7,8]$. Several studies have reported the optimization of cellulases and hemicellulases' production due to their role in biofuel production and associated costs $[9,10]$.

Cellulases and xylanases' production is mainly associated with microorganisms that are able to fully degrade lignocellulosic materials; it is, therefore, is of great relevance to determine the most-adequate strain or specialized inoculum to enhance cellulase production [11]. In this context, several inoculation strategies have been proposed for the production of different enzymatic compounds; they include the use of autochthonous microbiota for protease production [12], development of a specialized mixed consortium [13], and the use of specific cellulose-producing strains (mainly fungi) such as Trichoderma reseei [14-18]. T. reseei is a widely-referred to fungus for cellulase production using agroindustrial or agricultural wastes with a significant fibre content (cellulose $>25 \%$ ) as substrates [13]. An initial approach to the use of digestate as a substrate was reported by Santi et al. [19], where four white-rot fungi species were grown on $15 \mathrm{~g}$ of sterilized digestate. Pleurotusos treatus was able to use digestate as a sole nutrient source, with positive results in enzymatic production on 15-20 days of fermentation. However, developing a biorefinery process to valorise digestate remains a challenge.

The main goal of this work is to perform preliminary screening to determine the feasibility of valorising digestate into hemicellulolytic enzymes through a low-cost process based on SSF and avoiding biomass pretreatments; however, research on inoculum requirements must be first performed. To achieve this goal, SSF will be performed using different microbial strategies: (i) using the autochthonous microbiota present in the digestate; (ii) inoculating T. reseei and, (iii) developing a specialized inoculum.

To the best of the authors' knowledge, this is the first work focused on different inoculation strategies for the valorisation of digestate to produce high-value bioproducts at a lab and bench scale.

\section{Materials and Methods}

\subsection{Substrate Characterization}

Digestate and compost were kindly provided by a waste treatment facility in Granollers (Spain). The digestate used in this work came from the treatment of source-selected organic fraction of municipal solid waste (OFMSW) through a process that consisted of a mesophilic wet anaerobic digestion, followed by a solid/liquid separation with a screw press.

Both materials were stored at $4{ }^{\circ} \mathrm{C}$ for a maximum period of 15 days. Prior to its use, the digestate was hygienised at $70{ }^{\circ} \mathrm{C}$ for $1 \mathrm{~h}$, as it is a legal requirement specified in Regulation (EC) No 1069/2009 [20]. After hygienisation, digestate presented an average characterisation $(n=10)$ of dry matter $42 \pm 5$ (\%w.b), organic matter $70 \pm 8$ (\%d.b), $\mathrm{pH} 8.7 \pm 0.3, \mathrm{C} / \mathrm{N}$ ratio $11.8 \pm 0.7$, cellulose content $10 \pm 1$ (\%d.b), hemicellulose content $10.1 \pm 0.9$ (\%d.b) and lignin content $18 \pm 2$ (\%d.b).

\subsection{Inoculum Preparation}

Trichoderma reesei ATCC 26921 was purchased from "Colección Española de Cultivos Tipo" (CECT, Valencia, Spain). The strain was resuspended in liquid medium, as recommended by the providers ( $20 \mathrm{~g} / \mathrm{L}$ malt extract, $20 \mathrm{~g} / \mathrm{L}$ glucose, $1 \mathrm{~g} / \mathrm{L}$ soy peptone) and stored frozen at $-80^{\circ} \mathrm{C}$ in cryo-vials with $10 \%(v / v)$ of glycerol until use.

For growth of pellets, the cryopreserved T. reseei suspension was inoculated to sterile liquid medium ( $20 \mathrm{~g} / \mathrm{L}$ malt extract, $20 \mathrm{~g} / \mathrm{L}$ glucose, $1 \mathrm{~g} / \mathrm{L}$ soy peptone). The culture was stirred at $140 \mathrm{rpm}$, over $48 \mathrm{~h}$ at $30^{\circ} \mathrm{C}$ to be used as inoculum for SSF. 


\subsection{Solid-State Fermentation (SSF)}

\subsubsection{Experimental Set-Up}

Two different set-ups were used in this work. The lab scale set-up consisted of a series of $0.5 \mathrm{~L}$ reactors, placed in a water bath at constant temperature, with an inlet of water saturated airflow and an outlet of exhausted gases that passed through a dehumidifier water trap and then to an oxygen sensor (Figure 1).

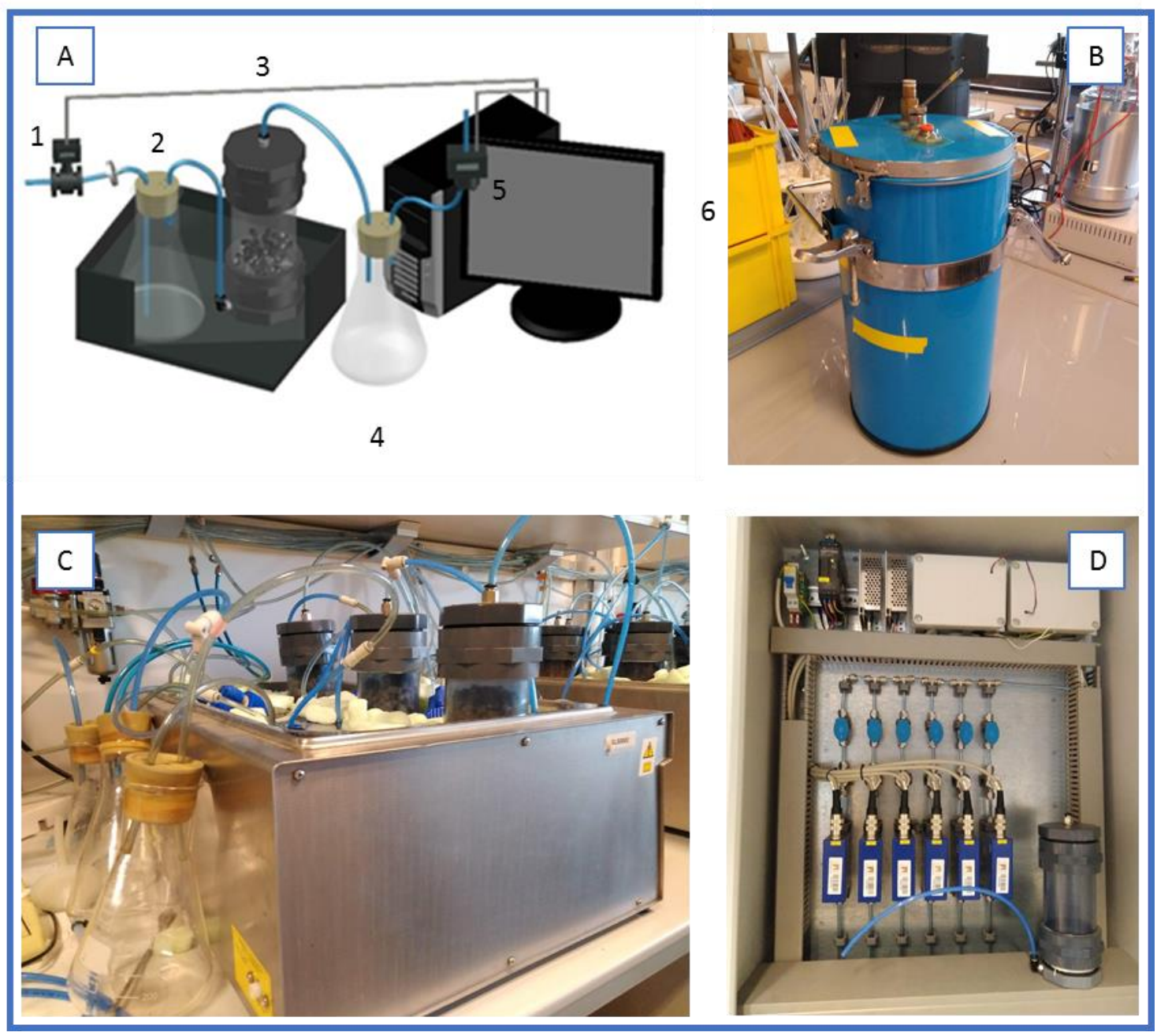

Figure 1. Experimental setups for solid-state fermentation. (A) Scheme, where: 1, flow meter; 2, humidifier; 3, bioreactor; 4 , water trap; 5 , oxygen sensor; 6 , data acquisition system; (B) bench-scale set-up; (C) lab-scale set-up; (D) detail of the self-made monitoring system and one lab-scale reactor.

A bench scale set-up consisted of a series of 4.5L air-tight packed bed reactors (adapting Dilvac glasses, Dewar, Day Impex Ltd., Essex, UK) thermally isolated to work under near-to-adiabatic conditions. Exhaust air came out from the top of the reactor and flowed to a dehumidification water trap and later to an oxygen sensor. Air flow and oxygen were monitored in both set-ups using a self-made data acquisition system based on Arduino ${ }^{\circledR}$. With these data, the specific oxygen uptake rate (sOUR) and cumulative oxygen consumption (COC) was calculated. 


\subsubsection{Monitoring Parameters}

Oxygen content and temperature was continuously monitored during SSF. Specific oxygen uptake rate (sOUR) was calculated by the following Equation (1) [21]:

$$
\mathrm{SOUR}=\mathrm{F} \cdot\left(0.209-\mathrm{y}_{\mathrm{O} 2}\right) \cdot \frac{\mathrm{P} \cdot 32 \cdot 60 \cdot 1000^{\mathrm{a}}}{\mathrm{R} \cdot \mathrm{T} \cdot \mathrm{DW} \cdot 1000^{\mathrm{b}}}
$$

where sOUR is the specific oxygen uptake rate $\left(\mathrm{g} \mathrm{O}_{2} \mathrm{~kg}^{-1} \mathrm{DM} \mathrm{h}^{-1}\right) ; \mathrm{F}$, airflow into the reactor $\left(\mathrm{mL} \mathrm{min}^{-1}\right)$; yo2, oxygen molar fraction in the exhaust air $\left(\mathrm{mol} \mathrm{O}_{2} \mathrm{~mol}^{-1}\right) ; \mathrm{P}$, pressure of the system assumed constant at 101,325 (Pa); 32, oxygen molecular weight $\left(\mathrm{g} \mathrm{O}_{2} \mathrm{~mol}^{-1} \mathrm{O}_{2}\right) ; 60$, conversion from minutes to hours; $1000^{\mathrm{a}}$, conversion from $\mathrm{mL}$ to $\mathrm{L} ; \mathrm{R}$, ideal gas constant $\left(8310 \mathrm{~Pa} \mathrm{~L} \mathrm{~K}^{-1} \mathrm{~mol}^{-1}\right)$; $\mathrm{T}$, temperature at $\mathrm{F}(\mathrm{K})$; DW, dry weight of solids in the reactor $(\mathrm{g}) ; 1000^{\mathrm{b}}$, conversion from $\mathrm{g}$ to $\mathrm{mg}$.

Cumulative oxygen consumption (COC, $\mathrm{g} \mathrm{O}_{2} \mathrm{~kg}^{-1} \mathrm{DM}$ ) was calculated through the numerical integration of continuous sOUR data obtained, according to Equation (2) [21]:

$$
\mathrm{COC}=\int_{0}^{\mathrm{t}} \mathrm{sOURdt}
$$

\subsubsection{Experimental Methodology}

Bulking agent and digestate were mixed in a 1:1 $(v / v)$ ratio to ensure appropriate porosity [22]. The bulking agent used for the lab scale and bench scale experiments were toothpicks and wood chips, respectively.

(a) Determination of inoculum requirements

Two sets of experiments were performed to assess the inoculum requirements of $95 \mathrm{~g}$ of hygienised digestate to produce cellulase and xylanase using the lab scale set-up, under constant temperature $\left(30{ }^{\circ} \mathrm{C}\right)$ and aeration $\left(20 \mathrm{~mL} \mathrm{~min}^{-1}\right)$.

The first one studied the effect of autochthonous microorganisms on enzyme production. The fermentations were performed using non-sterile mixtures. Additionally, considering that digestate comes from an anaerobic digestion process, it is likely that some easily assimilated nutrients may have been depleted; hence, nutrient supplementation with liquid medium was also analyzed, adding $10 \mathrm{~mL}$ of a nutrient solution ( $20 \mathrm{~g} / \mathrm{L}$ malt extract; $1 \mathrm{~g} / \mathrm{L}$ soy peptone) to the mixture.

The second set of experiments assessed the use of $T$. reseei as inoculum for enzyme production. With this objective, fermentations were performed using non-sterile mixture with $T$. reseei pellets in a $7 \%$ ( $w / w$, on wet basis). After inoculation, the solid matrix was manually homogenized.

Summarizing, four set of reactors were run: (a) hygienised digestate without inoculation, i.e., autochthonous microbiota (AM); (b) hygienised digestate without inoculation and supplemented with nutrients (AMS); (c) supplemented hygienised digestate inoculated with T. reseei under static conditions (TSS); (d) supplemented hygienised digestate inoculated with T. reseei with daily manual mixing (TSM).

These four set of experiments were performed in quadruplicates and one reactor was sacrificed and sampled at $48,65,84$ and 120 h of operation. Manual mixing was performed to obtain a representative sample. Cellulase and xylanase activities and other routine parameters were measured in the samples. sOUR profiles in figures and sOURmax values corresponded to values of the last reactor sampled to include all the experimental period for comprehension purposes. Furthermore, the standard deviation of the quadruplicates of sOUR did not surpass the $10 \%$ in any case.

(b) Development of a specialized microbiome

A sequential batch operation (SB) was performed as an alternative to achieve an adapted inoculum containing a specialized microbiome for cellulase and xylanase production. In the proposed 
system, compost was added at an early stage of the process, as it is a material with high intrinsic biodiversity [23] that could promote the production of the targeted enzymatic activity.

These experiments were conducted in duplicates using the bench scale set-up ( $4.5 \mathrm{~L}$ reactors). The solid mixture initially consisted of $90 \%$ of digestate and $10 \%$ compost as the inoculum ( $w / w$ ratio) and wood chips as the bulking agent (1:1 $v / v$ ratio), resulting in a total mass of $1.1 \mathrm{~kg}$. The duration of each batch was previously determined (data not shown), where the maximum sOUR and enzyme production were achieved at 1 and 3.5 days, respectively. Consequently, both periods were assessed as residence times for SB operation: SB1, using a residence time of 1 day (maximum sOUR) and SB2 using a retention time of 3.5 days (maximum enzymatic activity).

Once the first batch was completed, the operation began in cycles, where one part of the fermented solid acted as the inoculum for a new batch. This enabled adaptation of the microbiome in each batch $[13,24]$. To prepare a new batch, the reactor was opened and $90 \%$ of the material mass was removed for further analysis. The remaining $10 \%$ of the fermented solid was mixed with $90 \%$ of fresh digestate with a bulking agent to form a new batch. Digestate was stored at $4{ }^{\circ} \mathrm{C}$ for a maximum of 15 days. During this experiment, when a residence time of 3.5 days was assessed, it was found necessary to collect digestate twice from the biowaste industrial facility.

\subsection{Analytical Methods}

\subsubsection{Enzyme Extraction}

Cellulase and xylanase activities were performed in aqueous extracts obtained by mixing the fermented solids with $0.05 \mathrm{M}$ citrate buffer $(\mathrm{pH} 4.8)$ in a ratio $1: 15(w / v)$ and stirring at $200 \mathrm{rpm}$ for $30 \mathrm{~min}$ [25]. The extract was then centrifuged at 10,000 rpm for $10 \mathrm{~min}$ and filtered at $0.22 \mu \mathrm{m}$.

For protease determination, extraction was done by mixing the fermented solids with $50 \mathrm{mM}$ HCl-Tris ((hydroxymethyl) aminomethane) buffer ( $\mathrm{pH}$ 8.1) in a ratio 1:5 $(w / v)$ and stirred at $200 \mathrm{rpm}$ for $45 \mathrm{~min}$. Later, the extract was centrifuged at $4{ }^{\circ} \mathrm{C}$ and $10,000 \mathrm{rpm}$ over $10 \mathrm{~min}$ and later filtered at $0.45 \mu \mathrm{m}[12]$.

\subsubsection{Enzymatic Activity Determination}

Total cellulase activity was measured using filter paper assay (FPase), as recommended by IUPAC [26]. Final reducing sugars were measured using dinitrosalicylic acid reagent (DNS). The substrate was $1 \mathrm{~cm} \times 6 \mathrm{~cm}$ Whatman filter paper in $0.05 \mathrm{M}$ citrate buffer $(\mathrm{pH} 4.8)$ and the reaction run for $1 \mathrm{~h}$ at $50^{\circ} \mathrm{C}$. One unit of FPase (FPU) was expressed as the amount of enzyme that releases $1 \mu \mathrm{mol}$ of reducing sugars from Whatman filter paper per minute. Xylanase activity (Xyl) was determined according to Ang et al. [27]. The final product, xylose, was also measured with dinitrosalicylic acid reagent. One unit of xylanase activity (UA) was expressed as $1 \mu \mathrm{mol}$ of xylose released from xylan birch wood per minute. Cellulase activity is expressed as FPU g ${ }^{-1} \mathrm{DM}$, while xylanase activity is expressed as $\mathrm{UA} \mathrm{g}^{-1} \mathrm{DM}$.

Alkaline protease activity was determined following the methodology previously described [28]. The substrate was sodium caseinate in $\mathrm{HCl}$-Tris buffer $\left(\mathrm{pH}\right.$ 8.1) and the reaction run for $2 \mathrm{~h}$ at $50{ }^{\circ} \mathrm{C}$. TCA-soluble tyrosine derivatives were measured using the Folin-Ciocalteu reagent. Protease activity was expressed as $\mathrm{UA} \mathrm{g}^{-1} \mathrm{DM}$, and one unit of protease activity (UA) was defined as $1 \mu \mathrm{g}$ of tyrosine released from casein per minute.

\subsubsection{Routine Methods}

Moisture, total and volatile solids contents, and $\mathrm{pH}$ were determined according to standard procedures [29]. Cellulose, hemicellulose and lignin contents were determined by the method described in Van Soest et al. [30] using the Ankom200 Fibre Analyser incubator (Ankom Technology, Macedon, NY, USA). 


\subsubsection{Statistics}

Means among treatments were statistically compared with ANOVA using equal variances and applying the Tukey's pairwise comparison test $(p<0.05)$ with software MINITAB ${ }^{\mathrm{TM}}$ v17 (ㄷ) 2013 Minitab Inc., Pennsylvania, USA).

\section{Results and Discussion}

\subsection{Inoculation Requirements Determination}

A set of four experiments were performed to determine the inoculum requirements to produce cellulases and xylanases from digestate. Results are presented in Figure 2. In Figure 2A, the complete profile of biological activity and enzymatic production without inoculation under non-sterile conditions is presented, i.e., considering autochthonous microbiota (AM). Maximum average sOUR achieved was $1.4 \mathrm{~g} \mathrm{O}_{2} \mathrm{~kg}^{-1} \mathrm{DM} \mathrm{h}^{-1}$, reached at $12 \mathrm{~h}$ of SSF. This value demonstrates the moderate biodegradability of digestate [31], implying that it was not necessary to apply a pretreatment in this first work. Maximum cellulase activity was observed in Figure $2 \mathrm{~A}$ at $72 \mathrm{~h}$ of fermentation $\left(1.2 \pm 0.2 \mathrm{FPU} \mathrm{g}^{-1} \mathrm{DM}\right)$, showing a decreasing trend until almost negligible values. In this sense, digestate seemed to not be a suitable substrate for cellulase production [13], given that the maximum production values are in the lower rage of the reported references in Table 1. For xylanase production, a peak was observed at 3.5 days of operation with a value of $81 \pm 7 \mathrm{UA} \mathrm{g}^{-1} \mathrm{DM}$. These results suggest that the process of fermentation of digestate and autochthonous microorganisms is not suitable to produce cellulase, but it is suitable for xylanase production. It is likely that although digestate is rich in nutrients such as nitrogen, it lacks components that may induce cellulase production, such as cellobiose [32], or that xylanase is favored under these conditions and with this process time. Figure 2B shows the effect of the nutrient supplementation of digestate on biological parameters and enzyme production (AMS). sOUR presented a slight increase of nearly $20 \%$; however, both cellulase and xylanase reached lower values than in AM. This may be attributed to the fact that non-hemicellulolytic microorganisms could have used the added nutrients and diverted the substrate uptake for bioconversion to other products, as reflected by the increase of sOUR. Another aspect to consider is the initial $\mathrm{pH}$ of digestate around 8 . This will be a determinant for the proper proliferation of hemicellulolytic microorganisms, especially when using T. reseei as the inoculum [13].

Figure $2 \mathrm{C}, \mathrm{D}$ show SSF performance using T. reseei. It was expected that inoculating T. reseei would improve cellulase production due to the promising results reported by Santi et al. [19]. Additionally, as reported by Flodman and Noureddini [33], a positive effect on cellulase production was expected after nutrient supplementation and mixing. However, the results did not show any remarkable improvement.

Experiments considering T. reseei under static conditions (TSS) (Figure 2C) showed an average maximum sOUR of $1.5 \mathrm{~g} \mathrm{O}_{2} \mathrm{~kg}^{-1} \mathrm{DM} \mathrm{h}^{-1}$. An increase of enzyme activity was observed at $90 \mathrm{~h}$ for cellulase production, but not higher than initial activity $\left(1.1 \pm 0.3 \mathrm{FPU} \mathrm{g}^{-1} \mathrm{DM}\right)$. However, a xylanase activity peak occurred at $66 \mathrm{~h}$, being $31.3 \pm 15.8 \mathrm{UA} \mathrm{g}^{-1} \mathrm{DM}$.

Finally, experiments with daily mixing (TSM) (Figure 2D) presented an average maximum sOUR of $1.8 \mathrm{~g} \mathrm{O}_{2} \mathrm{~kg}^{-1} \mathrm{DM} \mathrm{h}^{-1}$. Again, mixing did not improve cellulase and xylanase production, obtaining xylanase peak at $90 \mathrm{~h}$ with a slightly lower value of $21 \pm 8 \mathrm{UA} \mathrm{g}^{-1} \mathrm{DM}$ in comparison with the static fermentation. These results are in accordance with those reported by Deschamps et al. [34], where a reduction of cellulase activity was observed between static and mixed SSF, decreasing from 18 to 11 FPU per gram of substrate. In an agitated solid matrix, aerial hyphae may be squashed sufficiently to reduce sporulation and growth [35]. In any case, cellulase activity did not surpass the value of 2 FPU g ${ }^{-1}$ DM. Although this cellulase activity value is in the lower range of the reported enzyme production (Table 1), some authors using crude extracts reported lower enzymatic activities around $0.5 \mathrm{FPU} \mathrm{g}^{-1} \mathrm{DM}$ [36]. None of the inoculated experiments (TSS and TSM) showed a visual growth of T. reesei at the end of the experiment. 
Table 1. Compilation of studies of cellulase production through SSF using filamentous fungi as inoculum.

\begin{tabular}{|c|c|c|c|c|c|c|c|c|}
\hline Reference & Enzyme & Microorganism & Substrate & SSF Time & Temperature & $\mathrm{pH}$ & Fermentation Sample & Max. Enzymatic Activity \\
\hline [15] & $\begin{array}{c}\text { Cellulase } \\
\text { Betaglucosidase }\end{array}$ & $\begin{array}{l}\text { Trichoderma reesei RUT C30 } \\
\text { Aspergillus niger MTCC } 7956\end{array}$ & $\begin{array}{l}\text { Wheat bran } \\
\text { Wheat bran }\end{array}$ & $72 \mathrm{~h}$ & $30^{\circ} \mathrm{C}$ & - & $\begin{array}{l}5 \mathrm{~g} \\
5 \mathrm{~g}\end{array}$ & $\begin{array}{l}22.8 \mathrm{FPU} / \mathrm{g} \text { DS } \\
21.39 \mathrm{U} / \mathrm{g} \mathrm{DS}\end{array}$ \\
\hline [37] & $\begin{array}{l}\text { Endoglucanase } \\
\text { Cellulase } \\
\text { Beta-glucanase } \\
\end{array}$ & Aspergillus terreus M11 & Wheat straw & $96 \mathrm{~h}$ & $45^{\circ} \mathrm{C}$ & - & $\begin{array}{l}5 \mathrm{~g} \text { (plus } \\
\text { mineral solution) }\end{array}$ & $\begin{array}{l}417 \mathrm{U} / \mathrm{g} \mathrm{DM} \\
166 \mathrm{U} / \mathrm{g} \mathrm{DM} \\
87 \mathrm{U} / \mathrm{g} \mathrm{DM}\end{array}$ \\
\hline [33] & $\begin{array}{c}\text { Cellulase } \\
\text { Betaglucosidase } \\
\text { Endoglucanase } \\
\text { Xylanases }\end{array}$ & $\begin{array}{l}\text { Trichoderma reesei (ATCC 26921) } \\
\text { Aspergillus oryzae (ATCC 12892) }\end{array}$ & Soybean hulls and wheat bran & $96 \mathrm{~h}$ & $30^{\circ} \mathrm{C}$ & 5 & $100 \mathrm{~g}$ & $\begin{array}{c}10.78 \mathrm{FPU} / \mathrm{g} \text { DS } \\
10.71 \mathrm{U} / \mathrm{g} \text { DS } \\
100.67 \mathrm{U} / \mathrm{g} \text { DS } \\
504.98 \mathrm{U} / \mathrm{g} \text { DS }\end{array}$ \\
\hline [16] & Cellulase & Trichoderma reesei $\mathrm{ZU}-02$ & $\begin{array}{l}\text { Corn cob residue and wheat } \\
\text { bran }+ \text { mineral solution }\end{array}$ & 5 days & $30^{\circ} \mathrm{C}$ & 4.5 (initial) & $\begin{array}{l}\text { Trays (thickness } \\
\text { about } 30 \mathrm{~cm} \text { ) }\end{array}$ & $\begin{array}{c}\text { 40-158 FPU/g (depending } \\
\text { on fermentation time) }\end{array}$ \\
\hline [38] & $\begin{array}{c}\text { Cellulase } \\
\text { Endoglucanase }\end{array}$ & Aspergillus fumigatus Z5 & Cornmeal & 4 days & $50^{\circ} \mathrm{C}$ & 9 & $\begin{array}{l}\text { Substrate (plus } \\
\text { mineral medium) }\end{array}$ & $\begin{array}{l}98.1 \mathrm{FPU} / \mathrm{g} \mathrm{dw} \\
341.3 \mathrm{U} / \mathrm{g} \mathrm{dw}\end{array}$ \\
\hline [39] & Xylanase & Aspergillus foetidus MTCC 4898 & $\begin{array}{c}\text { Agricultural waste }+ \\
\text { wastewater from anaerobic } \\
\text { digestion }\end{array}$ & $72-96 \mathrm{~h}$ & $30^{\circ} \mathrm{C}$ & - & $\begin{array}{c}5 \mathrm{~g} \text { (plus } \\
\text { liquid medium) }\end{array}$ & $\begin{array}{l}100-40,000 \mathrm{U} / \mathrm{g} \\
\text { (depending on the } \\
\text { agricultural residue) }\end{array}$ \\
\hline [40] & $\begin{array}{l}\text { Endoglucanase } \\
\text { Exoglucanase } \\
\text { Betaglucosidase }\end{array}$ & Trichoderma asperellum & Agave atrovirens fibres & $210-310 \mathrm{~h}$ & $29^{\circ} \mathrm{C}$ & - & - & $\begin{array}{l}12,860 \mathrm{U} / \mathrm{g} \\
3144.4 \mathrm{U} / \mathrm{g} \\
384.4 \mathrm{U} / \mathrm{g}\end{array}$ \\
\hline [19] & $\begin{array}{l}\text { Endoglucanase } \\
\text { Cellobiohydrolase } \\
\text { Xylanase }\end{array}$ & Pleurotus ostreatus & Corn silage digestate & 15-20 days & - & - & $15 \mathrm{~g}$ & $\begin{array}{c}2.3 \mathrm{U} / \mathrm{mg} \text { prot } \\
0.7 \mathrm{U} / \mathrm{mg} \text { prot } \\
3 \mathrm{U} / \mathrm{mg} \text { prot }\end{array}$ \\
\hline [17] & $\begin{array}{c}\text { Cellulase } \\
\text { Endoglucanse } \\
\text { Betaglucosidase } \\
\text { Xylanase }\end{array}$ & $\begin{array}{l}\text { Trichoderma reesei } \\
\text { Aspergillus oryzae }\end{array}$ & Soybean hull & $70 \mathrm{~h}$ & 30 & 5 & $10.24 \mathrm{~kg}$ & $\begin{array}{l}5.4 \mathrm{FPU} / \mathrm{g} \\
58.6 \mathrm{U} / \mathrm{g} \\
18.4 \mathrm{U} / \mathrm{g} \\
242 \mathrm{U} / \mathrm{g}\end{array}$ \\
\hline [18] & $\begin{array}{c}\text { Cellulase } \\
\text { Endoglucanse } \\
\text { Betaglucosidase } \\
\text { Xylanase }\end{array}$ & $\begin{array}{l}\text { Trichoderma reesei } \\
\text { Aspergillus oryzae }\end{array}$ & Rice straw and wheat bran & $120 \mathrm{~h}$ & 30 & - & $500 \mathrm{~g}$ & $\begin{array}{c}35.8 \mathrm{FPU} / \mathrm{g} \\
132.3 \mathrm{U} / \mathrm{g} \\
33.7 \mathrm{U} / \mathrm{g} \\
3106 \mathrm{U} / \mathrm{g}\end{array}$ \\
\hline
\end{tabular}



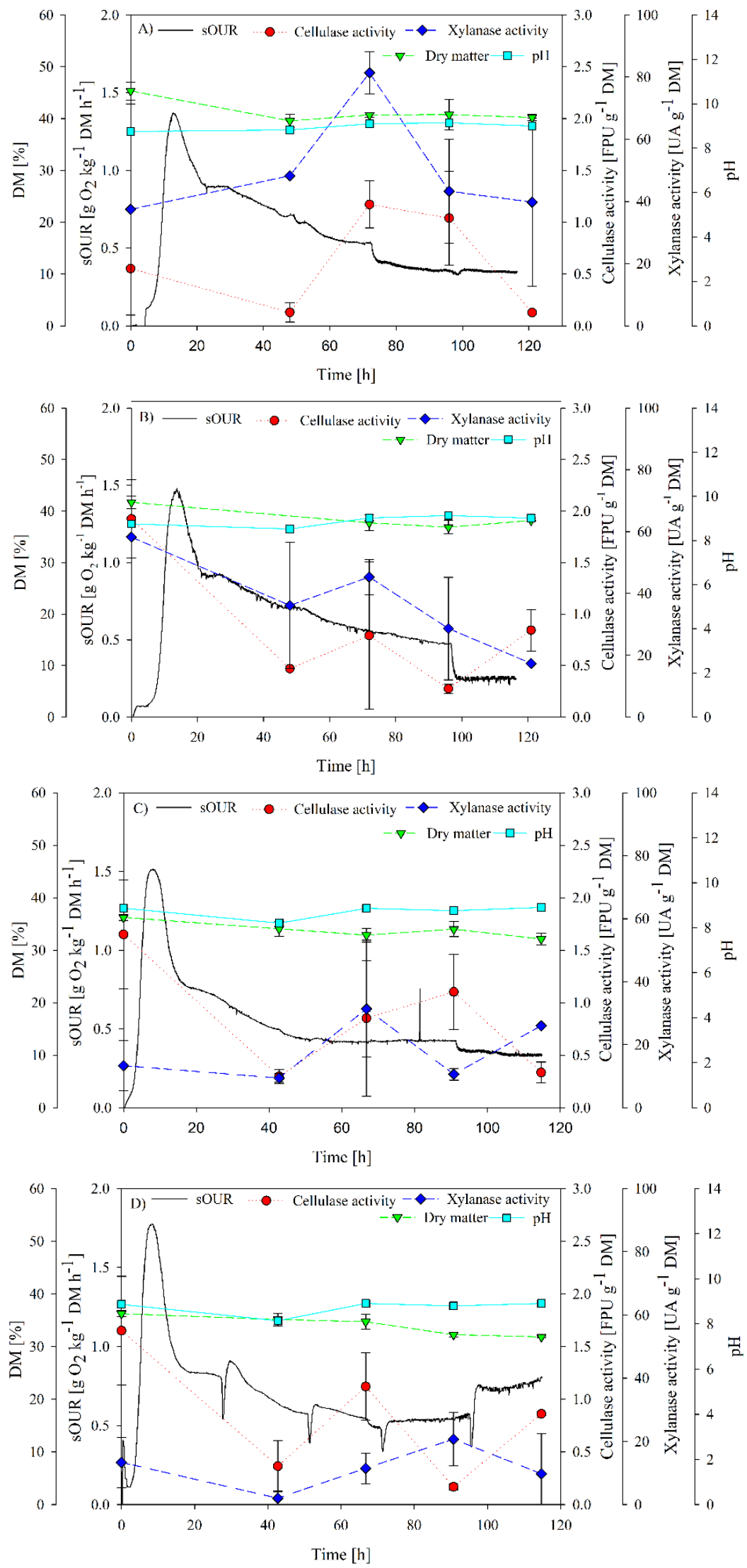

Figure 2. sOUR, cellulase activity, xylanase activity, dry matter (DM) and $\mathrm{pH}$ profiles for (A) AM; (B) AMS; (C) TSS and (D) TSM experiments. 
Cumulative oxygen consumption (COC) was also assessed as a biological activity indicator. COC values were $67.4 \mathrm{~g} \mathrm{O}_{2} \mathrm{~kg}^{-1} \mathrm{DM}, 70.4 \mathrm{~g} \mathrm{O}_{2} \mathrm{~kg}^{-1} \mathrm{DM}, 60.8 \mathrm{~g} \mathrm{O}_{2} \mathrm{~kg}^{-1} \mathrm{DM}$ and $80.7 \mathrm{~g} \mathrm{O}_{2} \mathrm{~kg}^{-1} \mathrm{DM}$ for AM, AMS, TSS and TSM experiments, respectively. No significant differences were observed in the first three experiments; however, the mixing seemed to have a positive effect on the global biological activity, improving the stabilization of organic matter.

One of the main hypothesis for the low cellulase and xylanase production using T. reseei as the inoculum is that alkaline $\mathrm{pH}$ values between 8 and 9 hindered fungus growth. T. reseei has been consistently reported as a cellulase producer in a range of $\mathrm{pH}$ between 5 and 7 [41,42]; hence, the alkaline $\mathrm{pH}$ could be the reason for the low enzyme productivities achieved. Digestates, either being liquid inside the anaerobic digester or solid after dehydrating, have a very high buffer capacity. This means that a large amount of weak acid solution must be applied to decrease the $\mathrm{pH}$. Some preliminary studies were done in order to lower the digestate $\mathrm{pH}$; however, as expected, high amounts of acid solution were required, increasing operational costs and obtaining a semi-solid solution not suitable for SSF performance. Thus, acid pre-treatment was not a suitable strategy in the framework of the project and was discarded.

Additionally, digestate showed a low content of fiber $(<10 \%)$ when compared with the most common substrates used for $T$. reseei, which ranged between $28-58 \%$ of cellulose content $[13,14,16,37]$. This indicates a low concentration of cellulase/xylanase inducers, which led to low enzyme production. Finally, longer process times as those reported in literature (Table 1) were not evaluated. In Cerda et al. [43], maximum enzymatic activity was achieved before the fifth day of process using non-pretreated lignocellulosic biomass and a consortium of bacteria and fungi. Observing the trends of enzymatic activity, longer process times were not considered, as it would not improve the process yield but would increase operation costs.

\subsection{SBR as Strategy to Obtain a Specialized Inoculum for Cellulase and Xylanase Production}

As autochthonous microbiota and T. reseei did not show significant positive effects on cellulase and xylanase production, a different approach was assessed, consisting of the development of a specialized inoculum by sequential batch operation, based on previous work [13].

In a preliminary experiment, a non-inoculated batch was performed in a $4.5 \mathrm{~L}$ reactor in order to analyze the biological activity present in the digestate. Digestate is a material coming from an anaerobic digestion process and for this reason, it could have low easily available organic matter or even poor biodiversity of aerobic biomass [3]. In consequence, a low self-heating capacity at pilot or industrial scale is expected. Results showed a maximum sOUR and temperature of $1.8 \mathrm{~g} \mathrm{O}_{2} \mathrm{~kg}^{-1} \mathrm{DM}$ $\mathrm{h}^{-1}$ at $12 \mathrm{~h}$ and $41.34{ }^{\circ} \mathrm{C}$ at $53 \mathrm{~h}$, respectively. The obtained conditions reflected that digestate provided a proper environment for the microorganisms to develop.

Figures 3 and 4 show the results of both assessed strategies SB1 and SB2, respectively. In SB1, the maximum sOUR in the first batch $\left(2 \mathrm{~g} \mathrm{O}_{2} \mathrm{~kg}^{-1} \mathrm{DM} \mathrm{h}^{-1}\right)$ occurred at $12 \mathrm{~h}$. After this first batch (inoculated with $10 \%$ compost), it was expected that the biological activity (sOUR) would either increase or maintain, as reported by other authors $[13,44]$ and the lag phase would shorten. However, after the third batch, the sOUR profile substantially decreased. This decrease could be related to the storage of digestate at $4{ }^{\circ} \mathrm{C}$; part of the remaining easily biodegradable organic matter could have been consumed by native microorganisms or the proliferation of non-hemicellulolytic microorganisms could have taken place, as described by Cerda et al. [43]. Temperature reached values over $45^{\circ} \mathrm{C}$ in all batches. Correlation studies were performed to relate oxygen consumption and maximum temperature reached. However, acceptable correlations were not found.

No significant increase of enzymatic activity was observed during the SB1 operation. Basically, maximum activities were observed at the initial time of the experiment with values of $1.4 \pm 0.3 \mathrm{FPU} \mathrm{g}^{-1}$ $\mathrm{DM}$ and $15.6 \pm 9.5 \mathrm{UA} \mathrm{g}^{-1} \mathrm{DM}$ for cellulase and xylanase activities, respectively. Additionally, the range of enzymatic activity was lower than the ranges reported by other authors using specific strains (Table 1) or mixed specialized inocula [43]. These results suggested that the process of 
adaptation by means of the SB1 operation did not favor cellulase nor xylanase production. However, other enzymatic or non-enzymatic products could be produced. In this sense, it has been reported that a variety of bioproducts are being produced at the same time in non-sterile fermentations, as a result of the metabolic activity of the complete microbiome in the solid matrix [23,43]. Protease is an enzyme that is commonly produced from organic solid wastes, especially in those with high protein content such as the digestate $(\mathrm{C} / \mathrm{N}$ ratio of $11.8 \pm 0.7)$ [12]. Therefore, one of the reasons for the low recovery of enzymatic activity could be the presence of non-targeted proteases that hydrolyse the produced enzymes in the aqueous extract. Other reasons could be related to the complex system of cellulases enzymatic groups. Cellulase activity recovery from the solid matrix can be extremely hindered by the attachment of the enzyme to lignin hydrolysates or even to the crystalline section of the cellulose [45]. In Marin et al. [46], different extraction strategies were tested, in terms of extraction ratio, agitation and solvent type, to maximize cellulase recovery after SSF.
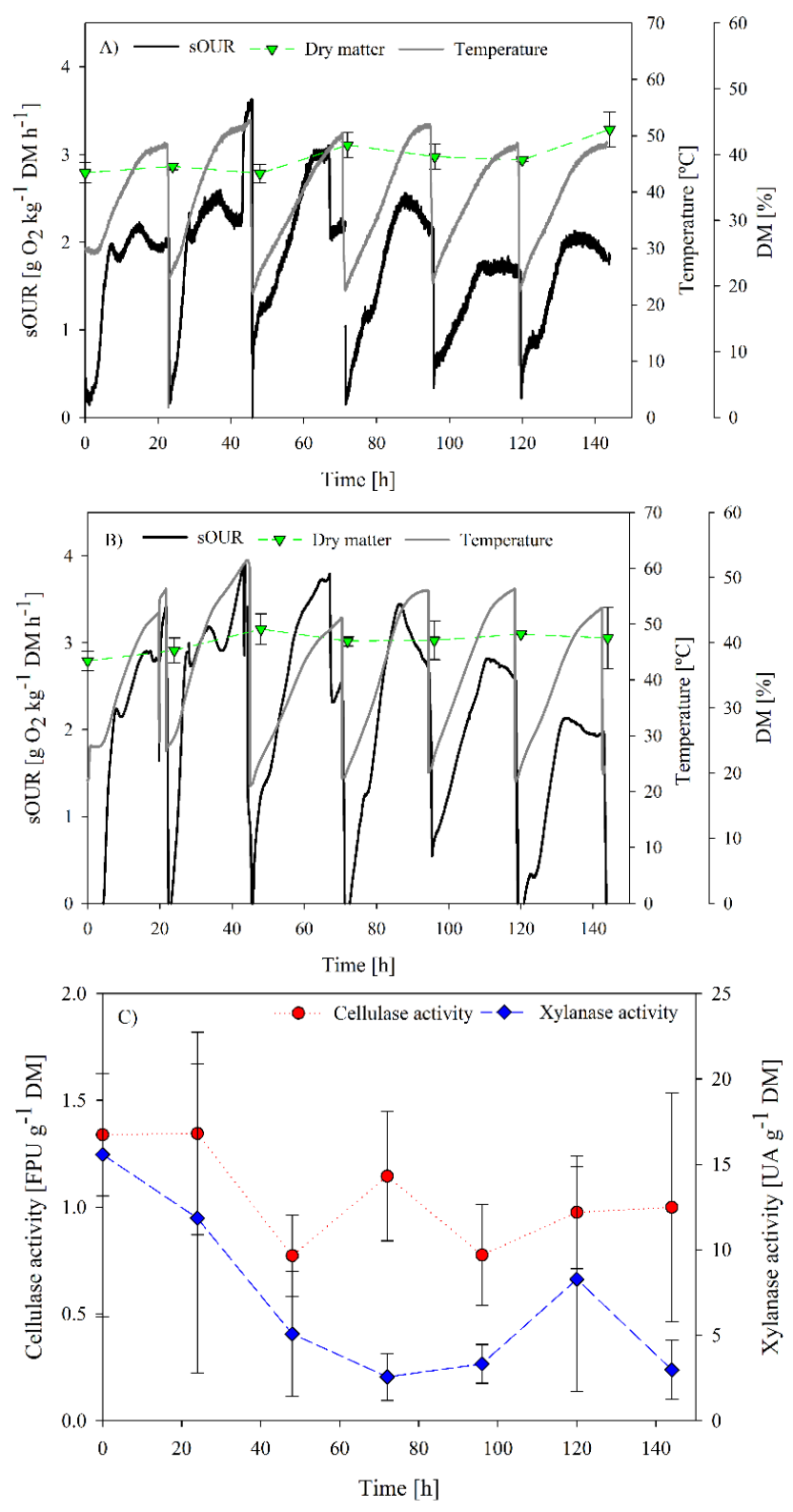

Figure 3. Process follow up of SB1 operation: (A) sOUR, temperature, dry matter and oxygen profiles for replicate 1; (B) sOUR, temperature, dry matter and oxygen profiles for replicate 2; (C) average cellulase and xylanase profiles. 
SB2 operational and enzyme production profiles are presented in Figure 4. In Cerda et al. [13], a more robust and reproducible operation was observed on increasing residence time. In that way, the microbiome has more time to adapt to the substrate. In addition, as observed in Figure $2 \mathrm{~A}$, a xylanase activity peak was obtained at 3.5 days of operation, hence, it is likely that the biomass present at that moment could be more adapted for xylanase production.

In Figure 4, it is observed that a more unstable operation was obtained with remarkable variation in maximum temperature and sOUR between batches, probably related to substrate variations due to longer storage periods. This variation of the maximum temperature reached can affect the selection of microbial population. In Cerda et al. [13], a stable temperature profile was obtained, allowing for clear microbial population change, obtaining a robust cellulase-producer inoculum.
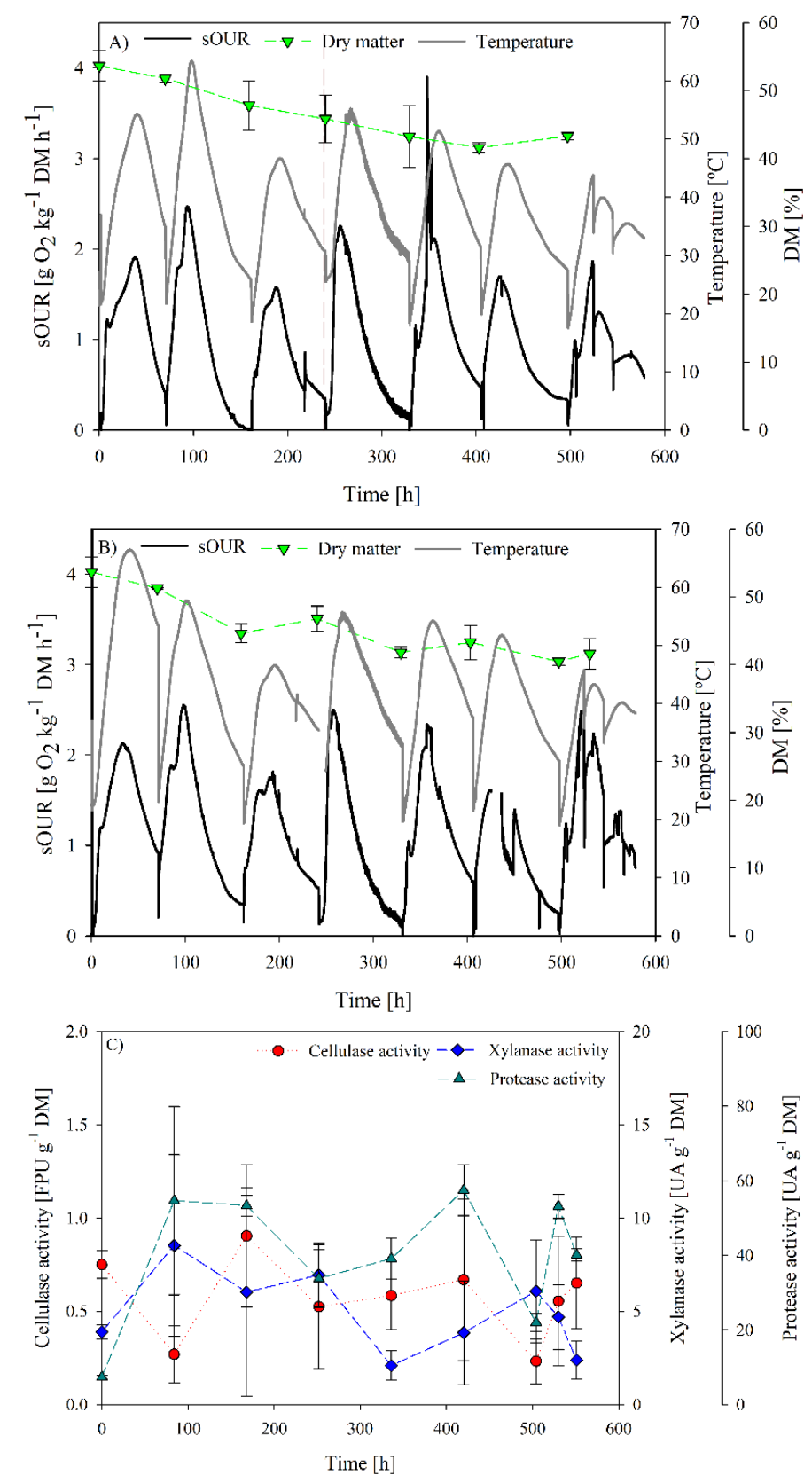

Figure 4. Process follow up of SB2 operation: (A) sOUR, temperature, dry matter and oxygen profiles for replicate 1; (B) sOUR, temperature, dry matter and oxygen profiles for replicate 2; (C) average cellulase, xylanase and protease profiles. 
Maximum sOUR in the second batch (2.4 and $2.5 \mathrm{~g} \mathrm{O}_{2} \mathrm{~kg}^{-1} \mathrm{DM} \mathrm{h}^{-1}$ ) was higher than in the first one, followed by the decrease of this value in the third batch. The same trend was observed from the fourth batch until the end of the experiment, as the fourth batch was fed with a fresh sampled digestate. Nevertheless, visual fungi growth was observed at the end of each batch.

Dry matter evolution showed a decrease over time. It can be explained as water produced during hydrolytic reactions condensed on the top of the reactor, modifying dry matter of the mixture. This can affect microbiome development due to oxygen transfer limitations generated by the compaction of the solid matrix $[12,13,47]$.

Cellulase activity measured was low with a discrete maximum of $0.9 \pm 0.4 \mathrm{FPU} \mathrm{g}^{-1}$ DM observed at $168 \mathrm{~h}$. However, this production is not significantly different to that observed at the beginning of the fermentations. In the case of xylanase production, a maximum of $8.5 \pm 4.8 \mathrm{UA} \mathrm{g}^{-1} \mathrm{DM}$ was obtained at day 3.5. Again, these values are in the lower range of the reported xylanase production by SSF, which normally range between 20 up to $3000 \mathrm{UA} \mathrm{g}^{-1} \mathrm{DM}$ depending on the inoculum and substrates used [48]. After the respective production peaks, enzyme activity decreased until negligible values in both cases.

Finally, protease activity was measured in the crude extracts in order to assess the influence of proteases production and low enzyme recovery in the SB2 operation. Results are presented in Figure $4 \mathrm{C}$. Protease activity profiles showed a significant increase from initial values to maximum values of 77 and $50 \mathrm{UA} \mathrm{g}^{-1} \mathrm{DM}$. However, this activity range was also low when compared to those reported by other authors [12,49]. In spite of the magnitude of protease activity levels, it is likely that their presence could have affected enzyme recovery during the SB2 operation.

\section{Conclusions}

Several strategies to develop a proper inoculum for cellulase and xylanase production were evaluated, assessing the feasibility to perform novel digestate valorization. Autochthonous microbiota and Trichoderma reseei addition to digestate showed no positive results. Digestate characteristics make it not suitable for $T$. reesei growth, and cellulase and xylanase production. The substrate composition variation due to the storage period supposes a drawback in the operation. The unstable temperature and sOUR profile in the SB operation probably interfered with the selection of a specific biomass and, thus, the achievement of specialized inoculum.

During sequential batch operation, cellulase and xylanase activity productions were very low compared to other literature values. Hydrolysis of enzymes by non-targeted protease and a poorly adapted biomass have resulted in critical aspects to consider when working with digestate as a substrate for SSF. In addition, the low recovery of enzymatic activity could also be attributed to different aspects, such as adsorption of cellulase into cellulose/lignin structure, or presence of inhibitors, among others.

Further research will be focused on the study of the inhibition of protease activity and assessment of endoglucanase, betaglucosidase and cellulase activity instead of sole analysis of total cellulase activity (FPase) to observe possible inhibition in the cellulose degrading process.

Author Contributions: Conceptualization, T.G. and A.S.; Methodology, A.C. and L.M.; Investigation, L.M.; Writing-Original Draft Preparation, L.M. and A.C.; Writing-Review \& Editing, R.B., T.G. and A.S.; Supervision, R.B. and T.G.; Project Administration, A.S.; Funding Acquisition, A.S.

Funding: This research was funded by the Horizon 2020 Programme (project DECISIVE) under grant agreement No 689229. Laura Mejias wants to thank Generalitat de Catalunya for her pre-doctoral grant (reference 2017 DI019).

Acknowledgments: The authors thank Consorci per a la Gestió dels Residus del Vallès Oriental, for providing digestate and compost. The authors also thank Aida Carretero and Mónica Estrada for their technical support during the development of this work.

Conflicts of Interest: The authors declare no conflict of interest. 


\section{References}

1. Biodegradable Waste-Environment-European Commission. Available online: http://ec.europa.eu/ environment/waste/compost/index.htm (accessed on 26 September 2017).

2. Tambone, F.; Scaglia, B.; D'Imporzano, G.; Schievano, A.; Orzi, V.; Salati, S.; Adani, F. Assessing amendment and fertilizing properties of digestates from anaerobic digestion through a comparative study with digested sludge and compost. Chemosphere 2010, 81, 577-583. [CrossRef] [PubMed]

3. Maynaud, G.; Druilhe, C.; Daumoin, M.; Jimenez, J.; Patureau, D.; Torrijos, M.; Pourcher, A.M.; Wéry, N. Characterisation of the biodegradability of post-treated digestates via the chemical accessibility and complexity of organic matter. Bioresour. Technol. 2017, 231, 65-74. [CrossRef] [PubMed]

4. Costa, A.; Ely, C.; Pennington, M.; Rock, S.; Staniec, C.; Turgeon, J. Anaerobic Digestion and Its Applications; U.S. Environmental Protection Agency: Washington, DC, USA, 2015; p. 15.

5. Teglia, C.; Tremier, A.; Martel, J.L. Characterization of solid digestates: Part 1, review of existing indicators to assess solid digestates agricultural use. Waste Biomass Valorization 2011, 2, 43-58. [CrossRef]

6. Singhania, R.R.; Sukumaran, R.K.; Patel, A.K.; Larroche, C.; Pandey, A. Advancement and comparative profiles in the production technologies using solid-state and submerged fermentation for microbial cellulases. Enzyme Microb. Technol. 2010, 46, 541-549. [CrossRef]

7. Lizardi-Jiménez, M.A.; Hernández-Martínez, R. Solid-state fermentation (SSF): Diversity of applications to valorize waste and biomass. 3 Biotech 2017, 7. [CrossRef] [PubMed]

8. Yazid, N.A.; Barrena, R.; Komilis, D.; Sánchez, A. Solid-State Fermentation as a Novel Paradigm for Organic Waste Valorization: A Review. Sustainability 2017, 9, 224. [CrossRef]

9. Wilson, D.B. Cellulases and biofuels. Curr. Opin. Biotechnol. 2009, 20, 295-299. [CrossRef] [PubMed]

10. Srivastava, N.; Srivastava, M.; Mishra, P.K.; Gupta, V.K.; Molina, G.; Rodriguez-Couto, S.; Manikanta, A.; Ramteke, P.W. Applications of fungal cellulases in biofuel production: Advances and limitations. Renew. Sustain. Energy Rev. 2017, 2379-2386. [CrossRef]

11. Hart, T.D.; De Leij, F.A.A.M.; Kinsey, G.; Kelley, J.; Lynch, J.M. Strategies for the isolation of cellulolytic fungi for composting of wheat straw. World J. Microbiol. Biotechnol. 2002, 18, 471-480. [CrossRef]

12. Abraham, J.; Gea, T.; Sánchez, A. Potential of the SSF of soy fibers residues by native microbial populations for bench-scale alkaline protease production. Biochem. Eng. J. 2013, 74, 15-19. [CrossRef]

13. Cerda, A.; Gea, T.; Vargas-García, M.C.; Sánchez, A. Towards a competitive solid-state fermentation: Cellulases production from coffee husk by sequential batch operation and role of microbial diversity. Sci. Total Environ. 2017, 589, 56-65. [CrossRef] [PubMed]

14. Brijwani, K.; Oberoi, H.S.; Vadlani, P.V. Production of a cellulolytic enzyme system in mixed-culture solid-state fermentation of soybean hulls supplemented with wheat bran. Process Biochem. 2010, 45, 120-128. [CrossRef]

15. Sukumaran, R.K.; Singhania, R.R.; Mathew, G.M.; Pandey, A. Cellulase production using biomass feed stock and its application in lignocellulose saccharification for bio-ethanol production. Renew. Energy 2009, 34, 421-424. [CrossRef]

16. Xia, L.; Cen, P. Cellulase production by solid-state fermentation on lignocellulosic waste from the xylose industry. Process Biochem. 1999, 34, 909-912. [CrossRef]

17. Brijwani, K.; Vadlani, P.V.; Hohn, K.L.; Maier, D.E. Experimental and theoretical analysis of a novel deep-bed solid-state bioreactor for cellulolytic enzymes production. Biochem. Eng. J. 2011, 58-59, 110-123. [CrossRef]

18. Dhillon, G.S.; Oberoi, H.S.; Kaur, S.; Bansal, S.; Brar, S.K. Value-addition of agricultural wastes for augmented cellulase and xylanase production through solid-state tray fermentation employing mixed-culture of fungi. Ind. Crops Prod. 2011, 34, 1160-1167. [CrossRef]

19. Santi, G.; Muzzini, V.G.; Galli, E.; Proietti, S.; Moscatello, S.; Battistelli, A. Mycelial growth and enzymatic activities of white-rot fungi on anaerobic digestates from industrial biogas plants. Environ. Eng. Manag. J. 2015, 14, 1713-1719.

20. European Parliament and Council Regulation (EC) No 1069/2009; Official Journal of the European Union: Brussels, Belgium, 2009; Volume 300, pp. 1-33.

21. Ponsá, S.; Gea, T.; Sánchez, A. Different Indices to Express Biodegradability in Organic Solid Wastes. J. Environ. Quality 2010, 39, 706. [CrossRef] [PubMed] 
22. Gea, T.; Barrena, R.; Artola, A.; Sánchez, A. Optimal bulking agent particle size and usage for heat retention and disinfection in domestic wastewater sludge composting. Waste Manag. 2007, 27, 1108-1116. [CrossRef] [PubMed]

23. López-González, J.A.; del Vargas-García, M.C.; López, M.J.; Suárez-Estrella, F.; Jurado, M.; Moreno, J. Enzymatic characterization of microbial isolates from lignocellulose waste composting: Chronological evolution. J. Environ. Manag. 2014, 145, 137-146. [CrossRef] [PubMed]

24. Eichorst, S.A.; Varanasi, P.; Stavila, V.; Zemla, M.; Auer, M.; Singh, S.; Simmons, B.A.; Singer, S.W. Community dynamics of cellulose-adapted thermophilic bacterial consortia. Environ. Microbiol. 2013, 15, 2573-2587. [CrossRef] [PubMed]

25. Dhillon, G.S.; Kaur, S.; Brar, S.K.; Verma, M. Potential of apple pomace as a solid substrate for fungal cellulase and hemicellulase bioproduction through solid-state fermentation. Ind. Crops Prod. 2012, 38, 6-13. [CrossRef]

26. Ghose, T.K. Measurement of cellulase activities. Pure Appl. Chem. 1987, 59. [CrossRef]

27. Ang, S.K.; Shaza, E.M.; Adibah, Y.A.; Suraini, A.A.; Madihah, M.S. Production of cellulases and xylanase by Aspergillus fumigatus SK1 using untreated oil palm trunk through solid-state fermentation. Process Biochem. 2013, 48, 1293-1302. [CrossRef]

28. Alef, K.; Nannipieri, P. Enzyme Activities; Academic Press: London, UK, 1995; ISBN 9780125138406.

29. Test Methods US Composting Council. Available online: https://compostingcouncil.org/test-methodsparameters / (accessed on 5 March 2018).

30. Van Soest, P.J.; Robertson, J.B.; Lewis, B.A. Methods for Dietary Fiber, Neutral Detergent Fiber, and Nonstarch Polysaccharides In Relation To Animal Nutrition. J. Dairy Sci. 1991, 74, 3583-3597. [CrossRef]

31. Barrena, R.; Gea, T.; Ponsá, S.; Ruggieri, L.; Artola, A.; Font, X.; Sánchez, A. Categorizing Raw Organic Material Biodegradability Via Respiration Activity Measurement: A Review. Compost Sci. Util. 2011, 19, 105-113. [CrossRef]

32. Yang, F.; Hanna, M.; Sun, R. Value-added uses for crude glycerol-A byproduct of biodiesel production. Biotechnol. Biofuels 2012, 5, 13. [CrossRef] [PubMed]

33. Flodman, H.R.; Noureddini, H. Effects of intermittent mechanical mixing on solid-state fermentation of wet corn distillers grain with Trichoderma reesei. Biochem. Eng. J. 2013, 81, 24-28. [CrossRef]

34. Deschamps, F.; Giuliano, C.; Asther, M.; Huet, M.C.; Roussost, S. Cellulase production by Trichoderma harzianum in static and mixed solid-state fermentation reactors under mesophilic conditions. Biotechnol. Bioeng. 1985, 27, 1385-1388. [CrossRef] [PubMed]

35. Mitchell, D.A.; Krieger, N.; Berovič, M. Solid-State Fermentation Bioreactors; Springer: Berlin, Germany, 2006; ISBN 978-3-540-31285-7.

36. Lever, M.; Ho, G.; Cord-Ruwisch, R. Ethanol from lignocellulose using crude unprocessed cellulase from solid-state fermentation. Bioresour. Technol. 2010, 101, 7083-7087. [CrossRef] [PubMed]

37. Gao, J.; Weng, H.; Zhu, D.; Yuan, M.; Guan, F.; Xi, Y. Production and characterization of cellulolytic enzymes from the thermoacidophilic fungal Aspergillus terreus M11 under solid-state cultivation of corn stover. Bioresour. Technol. 2008, 99, 7623-7629. [CrossRef] [PubMed]

38. Liu, D.; Zhang, R.; Yang, X.; Wu, H.; Xu, D.; Tang, Z.; Shen, Q. Thermostable cellulase production of Aspergillus fumigatus $\mathrm{Z} 5$ under solid-state fermentation and its application in degradation of agricultural wastes. Int. Biodeterior. Biodegrad. 2011, 65, 717-725. [CrossRef]

39. Chapla, D.; Divecha, J.; Madamwar, D.; Shah, A. Utilization of agro-industrial waste for xylanase production by Aspergillus foetidus MTCC 4898 under solid-state fermentation and its application in saccharification. Biochem. Eng. J. 2010, 49, 361-369. [CrossRef]

40. Nava-Cruz, N.Y.; Contreras-Esquivel, J.C.; Aguilar-González, M.A.; Nuncio, A.; Rodríguez-Herrera, R.; Aguilar, C.N. Agave atrovirens fibers as substrate and support for solid-state fermentation for cellulase production by Trichoderma asperellum. 3 Biotech 2016, 6. [CrossRef] [PubMed]

41. Loman, A.A.; Ju, L.K. Optimization of Enzymatic Process Condition for Protein Enrichment, Sugar Recovery and Digestibility Improvement of Soy Flour. JAOCS J. Am. Oil Chem. Soc. 2016, 93, 1063-1073. [CrossRef]

42. Ortiz, G.E.; Guitart, M.E.; Cavalitto, S.F.; Albertó, E.O.; Fernández-Lahore, M.; Blasco, M. Characterization, optimization, and scale-up of cellulases production by Trichoderma reesei cbs 836.91 in solid-state fermentation using agro-industrial products. Bioprocess Biosyst. Eng. 2015, 38, 2117-2128. [CrossRef] [PubMed] 
43. Cerda, A.; Mejías, L.; Gea, T.; Sánchez, A. Cellulase and xylanase production at pilot scale by solid-state fermentation from coffee husk using specialized consortia: The consistency of the process and the microbial communities involved. Bioresour. Technol. 2017, 243, 1059-1068. [CrossRef] [PubMed]

44. Cheirsilp, B.; Kitcha, S. Solid-state fermentation by cellulolytic oleaginous fungi for direct conversion of lignocellulosic biomass into lipids: Fed-batch and repeated-batch fermentations. Ind. Crops Prod. 2015, 66, 73-80. [CrossRef]

45. Gao, D.; Haarmeyer, C.; Balan, V.; Whitehead, T.A.; Dale, B.E.; Chundawat, S.P.S. Lignin triggers irreversible cellulase loss during pretreated lignocellulosic biomass saccharification. Biotechnol. Biofuels 2014, 7, 1-13. [CrossRef] [PubMed]

46. Marín, M.; Artola, A.; Sánchez, A. Optimization of Down-Stream for Cellulases Produced Under Solid-State Fermentation of Coffee Husk. Waste Biomass Valoriz. 2018. [CrossRef]

47. Cerda, A.; El-Bakry, M.; Gea, T.; Sánchez, A. Long term enhanced solid-state fermentation: Inoculation strategies for amylase production from soy and bread wastes by Thermomyces sp. in a sequential batch operation. J. Environ. Chem. Eng. 2016, 4, 2394-2401. [CrossRef]

48. El-Bakry, M.; Abraham, J.; Cerda, A.; Barrena, R.; Ponsá, S.; Gea, T.; Sánchez, A. From Wastes to High Value Added Products: Novel Aspects of SSF in the Production of Enzymes. Crit. Rev. Environ. Sci. Technol. 2015, 45, 1999-2042. [CrossRef]

49. El-Bakry, M.; Gea, T.; Sánchez, A. Inoculation effect of thermophilic microorganisms on protease production through solid-state fermentation under non-sterile conditions at lab and bench scale (SSF). Bioprocess Biosyst. Eng. 2016, 39, 585-592. [CrossRef] [PubMed]

(C) 2018 by the authors. Licensee MDPI, Basel, Switzerland. This article is an open access article distributed under the terms and conditions of the Creative Commons Attribution (CC BY) license (http:/ / creativecommons.org/licenses/by/4.0/). 